\title{
PREDICTING THE PERFORMANCE AND SURVIVAL OF ISLAMIC BANKS IN MALAYSIA TO ACHIEVE GROWTH SUSTAINABILITY
}

\author{
Noraina Mazuin Sapuan, Suzaida Bakar, Hamidah Ramlan* \\ Department of Finance and Economics, Universiti Tenaga Nasional, Muadzam Shah, Pahang, \\ Malaysia
}

\begin{abstract}
In Malaysia, the growth of the Islamic financial industry has increased tremendously in line with the Government's ambition to make Malaysia as an international hub for Islamic finance since 2010. With the increasing number of foreign players in this industry plus with the increasing demand from domestic and foreign customers would further enhance the possibility for Malaysia to achieve this ambition. Currently, according to the Economic Transformation Programme, 2012 Malaysia is the world's third largest market for Shariah assets that cover Islamic banks, Takaful, and sukuk. Malaysia as one of the main contributors to the global Islamic financial assets with Islamic assets in Malaysia grew by $23.8 \%$ in 2011 from RM350.8bil to RM434.6bil. The issues of predicting the performance and the survival of Islamic Banks in Malaysia become amongst crucial issues in academic research. By employing multi - layer perceptron neural network and pooled regression, we found that total assets/ size of the Islamic banks (GROWTH) have high weightage and significantly influence in predicting the performance and the survival of Islamic banks in Malaysia. With the increasing number of Islamic banking institutions in Malaysia, this study can give insight on the sustainability of the Islamic banking system in Malaysia for the benefit of the investors, shareholder and depositors.
\end{abstract}

Keywords: Performance, Survival, Islamic Banks, Multi - layer Perceptron Neural Network and Pooled Regression and Growth Sustainability

\section{INTRODUCTION}

The Islamic financial industry has grown tremendously since it first emerged in the 1970's. Globally, Islamic finance assets grew at double-digit rates in the past decade to reach an estimated $\$ 1.8$ trillion at the end of 2013, with further growth expected (Ernst \& Young, 2014; IFSB, 2014). This growth reflects demand from large and relatively Muslim and nonMuslim populations seeking to deposit money or invest in sharia-compliant banks and financial products - those that are acceptable under Islamic law. Furthermore, by emphasizing the need for transactions to be supported by genuine trade or business related activities, Islamic banking sets a higher standard for investments and promotes greater accountability and risk mitigation.

*Corresponding author's email: Hamidah@uniten.edu.my 
Basically, with the rapid growth of Islamic finance industry worldwide, especially Islamic banking industry, many studies has studied the importance of this industry. The earliest study on Islamic banking system is done by Nienhaus (1983) examined the usage of profit loss sharing (PLS) instruments in Islamic bank and the alternative method to measure bank profit through profit sharing ratio. Meanwhile, Samad and Hassan (2000) are the pioneer of the study of determinants of Islamic bank's profitability which is linked to the efficiency and profitability of Islamic banks.

In terms of bank profitability, previous studies have utilized the income before tax and income after tax over total assets, total equity and total deposits calculate the profitability ratio, namely ROA, ROE and ROD as well as bank net margin as the dependant variables. Especially on the determinants of Islamic bank's profitability.

Most of the previous researcher concentrates their study on the determinants of conventional banks' profitability in either cross-country or individual countries' banking system. Only a few similar studies are carried out, particularly for Islamic bank. The earliest study on the determinants of Islamic bank's profitability which is linked to the efficiency and profitability of Islamic banks is done by Samad and Hassan (2000). With the increasing demand of the Islamic banks instruments' worldwide, especially in the 1990s, many researchers have taken the initiative to do the same research in this field. How et al. (2005) and Rosly and Abu Bakar (2003) focus on the performance of Islamic banks in Malaysia, while Turen (1995) on Bahrain Islamic Bank and Bashir (2000) on Middle Eastern countries. bank profitability is determined by internal and external factors. Internal factors can be viewed as factors that can be controlled by the bank management and can be also classified as bank specific variables such as bank size, leverage, assets and liability portfolio mix, overhead expenses, liquidity ratio, capital ratio, ownership and capital adequacy. Meanwhile, the external factors could be expressed as variables which are not associated with bank management. Basically, external factors can be divided into two types, i.e. industry specific determinants and macroeconomic variables.Among the widely discussed industry specific variables are competition, regulation, concentration, market share, ownership and scarcity of capital. As far as the internal factors are considered, Bashir (2000), Hassan and Bashir (2003) and Sanusi and Mohammed (2004) discovered that Islamic banking profitability responds positively to the increases in capital ratios. The results revealed that larger equity to total asset ratio leads to more profit margins. In terms of external factors, Bourke (1989) found that concentration has moderate and positive related to pre-tax returns on assets. Molyneux and Thornton (1992) further extended Bourke's methodology and examine bank profitability in eighteen European countries between 1986 and 1989. There is a significant positive relationship between return on capital and concentration and a positive relationship for nominal interest rates. Concentration shows a positive, statistically significant correlation with pre-tax return on assets. Athanasoglou et al. (2008) found that industry-specific i.e. ownership and concentration are insignificant in explaining profitability. Meanwhile, the latest studies done by Sapuan \& Roly (2015) shown that bank profitability, bank specifics variables and financial structure are cointegrated in long run.

In view of the above, this paper will discuss on the performance of the Malaysian Islamic bankings and its survival in the future especially with the increasing competition from internaltional participants whether in Malaysia or from foreign market. 
Empirical studies on the prediction in finance had utilize various methods of soft computing system such as multi layered feed forward neural network trained with backpropagation (MLFF-BP), a probabilistic neural network (PNN), multivariate discriminant analysis (MDA) and support vector machine (SVM)(Ravi et al, 2007). Tam and Kiang (1992), Gunay and Ozkan (2007) and Celik and Karatepe (2007) have used neural networks to predict bank failure and bankruptcy.

Meanwhile, Odom and Sharda (1990), Koster et al. (1990), Coats and Fant (1993), Tsukuda and Baba (1994), and Altman et al. (1994) have used the similar tool to predict company bankruptcy. Dutta and Shekhar (1988) and Surkan and Singleton (1990) predict the ratings of corporate bonds and their expected profitability. Yoon and Swales (1990) predicts stock price performance. White (1988), Kamijo and Tanigawa (1990), and Kryzanwski et al. (1993) predict common stock returns. Mitchell and Pavur (2002), Handzic et al. (2003), Molharta and Molharta (2003) and Eletter and Yassen (2010) on loan application decision.

Tam and Kiang (1992) examined bank bankruptcy prediction using ANN and compare it with linear classifier, logistic regressions, $\mathrm{kNN}$ and ID3. The data sample consists of Texas banks that failed in the period 1985-1987. The data are comprised of bank data one year and two years prior to failure. As a control measure, a failed bank was matched with a non-failed bank in terms of (1) asset size, (2) number of branches, (3) age, and (4) charter status. In each period, 118 banks (59 failed and 59 non-failed) were selected as the training sample. Each bank is described by 19 financial ratios that have been used in previous studies. The empirical results show that neural network is a promising method of evaluating bank conditions in terms of predictive accuracy, adaptability, and robustness compared to other forecasting method.

In terms of prediction on bank performance for Islamic banks, Al-Osaimy (1998) used a data sample of twenty six Islamic banks worldwide has been collected for the period 1991-1993. Kohonen neural network was used to group the Islamic banks into high and low performance groups using the seven financial ratios. Twelve banks have been indicated as a high performance group and fourteen banks as a low performance group. The three layers Backpropagation neural network was built to predict the Islamic bank's performance. The network was trained on the one year prior to the performance year data set while using the performance year data as a test set. Meanwhile, the two years prior to the performance year data set was used as a holdout sample to check the network prediction abilities. When the network was applied, the results showed high prediction abilities and show a significant method as a useful early warning signal for various types of performance whether bankruptcy, insolvency or failure.

Additionally, Abu Bakar and Mohd Tahir (2009) further extend the study by Al-Osaimy (1998) by making the prediction the performance of Islamic banks in Malaysia base on thirteen banks from 2001 to 2006 by comparing multiple linear regressions (MLR) and artificial neural network (ANN) in order to search for accurate forecasting results. ROA was used to measure bank performance, meanwhile seven variables, including liquidity, credit risk, cost to income ratio, size, concentration ratio, inflation and GDP were used as 
independent variables. The prediction of bank performance is measured using the mean square prediction error and the R-squared value which indicates the proportion of variation explained by the validation model. The study concludes that ANN gives extremely accurate results and outperformed the MLR in predicting bank performance.

Meanwhile, Gunay and Ozkan (2007) and Celik and Karatepe (2007) studied on prediction of bank failure in the Turkish banking sector using ANN. The results of both studies are in line with the finding by Tam and Kiang (1992) and Abu Bakar and Mohd Tahir (2009) whereby ANN is the best method to predict bank crises and can become an alternative early warning system that can be used along with other common method used in measuring bank performance such as financial ratio, comprehensive bank assessment and econometrics model.

\section{RESEARCH DESIGN}

The data were collected from 16 Islamic banking annual reports from the period of 2005 to 2014. The selected banks were Islamic commercial banks and the commercial banks that have been classified under the Islamic banking scheme and whereby the operation recently been categorized as subsidiaries Islamic banking. All related data were collected from the IFS database. For the data analysis, we employed supervised machine learning neural network method (Odom and Sharda, 1990). Multilayer perceptron algorithm has been used in order to detect the highest possible predictors that influence the performance and the survival of the Islamic banks in Malaysia. One hidden layer have been use and the activation function for input layer is hyperbolic tangent. In order to see the direction of the relationship between the inputs (predictors) and output (ROA), pooled regression analysis (ordinary least square) have been employed.

\section{Dependence Variables}

The endogenous factor of this study is bank profitability that measured through the balance sheet ratios that represented by Return on Assets (ROA) as a measurement of asset utilization.

$$
\mathrm{ROA}=\text { Income after tax or zakah /total assets. }
$$

\section{Independence Variables}

We identified the exogenous factors as bank characteristics that consist of variables as listed as follows:

GROWTH $=\log$ of total asset

Credit risk $(\mathrm{LTA})=$ total loans / total assets

Bank efficiency $(\mathrm{NIE})=$ Non interest income $/$ total assets

\section{Estimation Model}

The regression model can be specified as follows: 


$$
\mathrm{ROA}_{i t}=\alpha_{0}+\alpha_{1} \mathrm{GROWTH}_{\mathrm{it}}+\alpha_{2} \mathrm{LTA}_{\mathrm{it}}+\alpha_{3} \mathrm{NIETA}_{\mathrm{it}}+\varepsilon_{\mathrm{it}}
$$

(1)

Where;

ROA= bank profitability

GROWTH = bank size represents by log of total assets,

LTA $=$ ratio between total loan over total assets, (credit risk)

NIETA $=$ ratio between non-interest earning over total assets (Bank efficiency)

$\varepsilon=$ the error term.

In machine learning, artificial neural networks (ANNs) are a family of statistical learning algorithms inspired by biological neural networks (the central nervous systems of animals, in particular the brain) and are used to estimate or approximate functions that can depend on a large number of inputs and are generally unknown. Artificial neural networks are generally presented as systems of interconnected "neurons" which can compute values from inputs, and are capable of machine learning as well as pattern recognition thanks to their adaptive nature.

Like other machine learning methods - systems that learn from data - neural networks have been used to solve a wide variety of tasks that are hard to solve using ordinary rule-based programming, including computer vision and speech recognition.

IBM SPSS Neural Networks 19 has been used to run the data. Below are an architecture or framework for this study in neural network architecture:

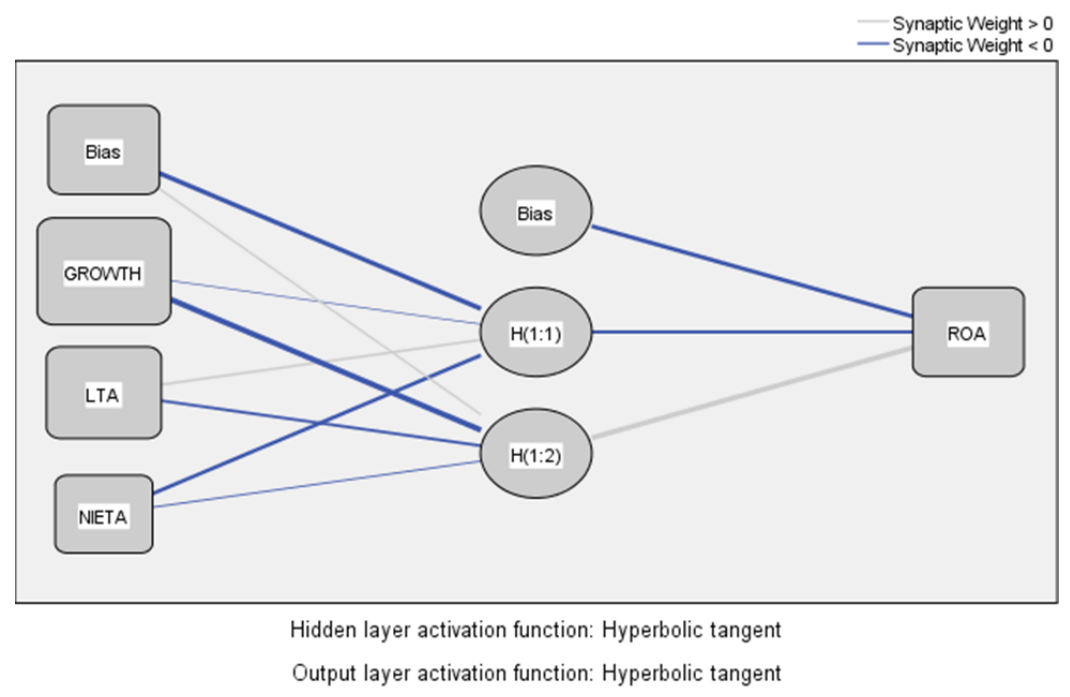

\section{FINDINGS}

\section{Neural Network Analysis}


Table 1 Case processing summary, shows that from the total of 112 cases, 82 cases were assigned to the training sample and 30 to the testing (holdout) sample and no cases were excluded from the analysis.

Table 1: Case processing summary

\begin{tabular}{ccc}
\hline Sample & $\mathbf{N}$ & Percent \\
\hline Training & 82 & $73.2 \%$ \\
Testing & 30 & $26.8 \%$ \\
Valid & 112 & $100.0 \%$ \\
Excluded & 0 & \\
Total & 112 & \\
\hline
\end{tabular}

Based on Table 2, the importance of an independent variables as measured of how much the network's model-predicted value changes for different values of the independent variable. Normalized importance is simply the importance values divided by the largest importance values and expressed as percentages.

Table 2: Independent Variable Importance

\begin{tabular}{ccc}
\hline Input & Importance & $\begin{array}{c}\text { Normalized } \\
\text { Importance }\end{array}$ \\
\hline Log Total Asset(GROWTH) & 0.565 & $100.0 \%$ \\
Loans to Total Asset(LTA) & 0.328 & $58.1 \%$ \\
Non Interest Earning to Total & 0.107 & $18.9 \%$ \\
Asset(NIETA) & & \\
\hline
\end{tabular}

The importance chart is simply a bar chart of the values in the importance table, sorted in descending value of importance. Based on Figure II, it appears that the most important predictors related to the performance and survival of Islamic banks in Malaysia is the bank growth (GROWTH) where it represent the greatest effect on how the network classifies bank survival; then followed by loans to total asset (LTA) which represent the credit risks and finally the non interest earning to total assets(NIETA) representing bank efficiency; but one of the drawback of neural network it cannot tell the "direction" of the relationship between all predictors and the predicted performance or survival of the Islamic banks. Therefore, to reveal the direction of the relationship between inputs and output, pooled regression analysis has been employed. 


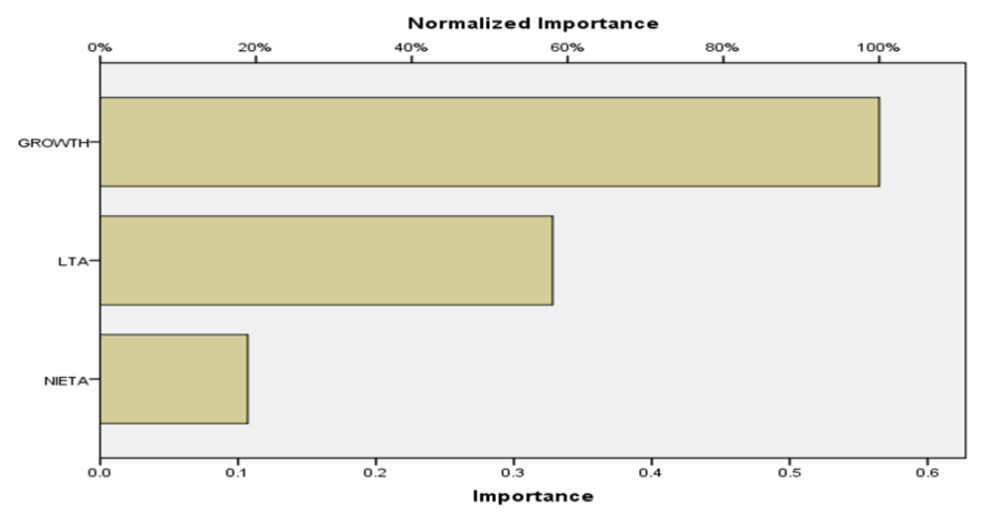

Figure 2. Importance Chart

\section{Pooled Regression Analysis}

In Table 3, the results indicates a negative significant relation between GROWTH and credit risks with the performance and the survival of Islamic banks in Malaysia. Theoretically, it is confirmed that Islamic banks will find difficulties when the loan loss provision(credit risks) increases where it will affects earnings before zakat and depreciation. When banks in this condition for two consecutive years (where the EBZDA is negative) (Asquith, 1994), these particular bank will be considered as financially distressed banks. In this case, there is possibility the bank will plan for merger and acquisition with others dominance banks; as happened during Asian financial crisis in 1997. From our findings, it shows that GROWTH which represent by total assets of the banks have negative significant influence with the performance and the survival of the Islamic banks. If Islamic banks have so many branches it might increase the operating cost and it will reduce the profits of the Islamic banks; where it might contribute to the deteroriation in Islamic bank growth sustainability. The findings is consistent with the real situation in banking industry nowadays such for example the closing of some CIMB branches all over Malaysia, it is due to the high cost in operating expenses and it will reduce the profits of the banks. The arguments are consistent with Yap et.al (2011) and Alifiah et.al (2013), which shows that the likelihood of firms' financial distress is linked with working capital, cash flow of the firms, the levels firms' debt and not with efficiency ratio. Our findings also consistent with Abu Bakar and Mohd Tahir (2009),

Table 3: Pooled Regression analysis

\begin{tabular}{lcc}
\hline \multicolumn{1}{c}{ DV } & \multicolumn{2}{c}{ ROA } \\
\hline \multicolumn{1}{c}{ IV } & $\beta$ & $\mathrm{t}$ \\
Log Total Asset(GROWTH) & $-0.6142^{* * *}$ & -2.7491 \\
Loans to Total Asset(LTA) & $-1.4250^{* *}$ & -1.7595 \\
Non Interest Earning to Total Asset (NIETA) & -0.1045 & -0.0940 \\
\multicolumn{1}{c}{} & $7.2859^{* * *}$ & 4.1631 \\
& Adj R ${ }^{2}=0.0566$ \\
\multicolumn{2}{c}{ F-stat $=3.2202 * *$} \\
\hline
\end{tabular}

Model Equation: 


$$
\text { ROA }=7.2859-0.6142 * \mathrm{GROWTH}_{\mathrm{it}}-1.4250 * \mathrm{LTA}_{\mathrm{it}}-0.1045 * \mathrm{NIETA}_{\mathrm{it}}+\varepsilon_{\mathrm{it}}
$$

\section{CONCLUSION}

The hybridization of neural networks was a very popular phenomenon in investigated business disciplines. Even though that specific hybrid networks might work well only for particular tasks, our opinion to suggest that proper integration of metaheuristic methods into the neural network methodology might be a key for achieving the optimal findings. To conclude, neural networks have been successfully applied in wide range of business tasks and were able to detect complex and nonlinear relationships without requiring any specific assumptions about the distribution or characteristics of the data. As from our findings, we able to predict the survival predictors for the Islamic banks and able to identify the directions for each predictors. As a conclusion our findings are consistent with Yap et.al (2011) and Alifiah et.al (2013), which shows that the likelihood of firms' financial distress is linked with the levels credit risks and not with efficiency ratio. While for GROWTH it is supported by Abu Bakar and Mohd Tahir (2009). As for the recommendation, the future development on the findings may also integrate with non-linear predictors such as input from survey that pertaining to the characteristics of the CEO and board of directors and measure whether there is any possible integration with the likelihood of Islamic banks survival in Malaysia.

\section{ACKNOWLEDGEMENTS}

A special thanks to Universiti Tenaga Nasional as for being our sponsor for this Internal Grant Scheme and this is a part of the findings from this research grant.

\section{REFERENCES}

Abu Bakar, N.M. and Mohd Tahir. I. (2009), "Applying Multiple Linear Regression and Neural Network to Predict Bank Performance”, International Business Research, vol 2, no 4, pp.176-181.

Alifiah, M. N., Salamudin, N., \& Ahmad, I. (2013), "Prediction of Financial Distress Companies in the Consumer Products Sector in Malaysia", Jurnal Teknologi, 64(1).

Al-Osaimy, M.H. (1998), "A Neural Networks System for Predicting Islamic Banks Performance", Journal of King Abdul Azis University: Islamic Economic \& Administration, vol.11, no.1, pp.33-46.

Altman, E., G. Marco and F. Varetto, (1994), "Corporate Distress Diagnosis: Comparisons Using Linear Discriminant Analysis and Neural Networks (the Italian Experience)", Journal of Banking and Finance, Vol. 18, pp. 505-529. 
Athanasoglou, P P, Brissimis, S N, and Delis, M. D. (2008), "Bank-specific, industry-specific and macroeconomic determinants of bank profitability". International, Financial Markets, Institution and Money, vol. 18, 21-136.

Bashir, A. (2000), "Assessing the performance of Islamic banks: Some evidence from the Middle East". Paper presented at the ERF ${ }^{\text {th }}$ meeting in Jordan.

Bourke, P. (1989), "Concentration and other determinants of bank profitability in Europe, North America and Australia", Journal of Banking and Finance, vol.13, pp.65-79.

Celik A.E. \& Karatepe Y. (2007), "Evaluating and forecasting banking crises through neural network models: An application for Turkish banking sector". Expert Systems with Applications,33 pp: 809-815.

Coats, P.K. and Fant, L.F. (1993), "Recognizing financial distress patterns using a neural network tool", Financial Management, Vol. 22 No. 3, pp. 142-56.

Demirguc-Kunt, A. and Huizinga, H. (2000), "Financial structure and bank profitability". Policy Research Working Paper Series 2430. The World Bank.

Dutta, S. and S. Shekhar, (1988), "Bond Rating: A Non-Conservative Application of Neural Networks", Proceedings of IEEE International Conference on Neural Networks, IEEE Press, Alamitos, CA, Vol. 2, pp. 443-450.

Ernst and Young, (2014), World Islamic Banking Competitiveness Report 2013-14: The Transition Begins (London).

Eletter, S.F. \& Yaseen, S. G. (2010), “Applying Neural Networks for Loan Decisions in the Jordanian Commercial Banking System", International Journal of Computer Science and Network Security, VOL.10 No.1, pp: 209-214

Gunay, O. E. N. and Ozkan, M. (2007), "Prediction of bank failures in emerging financial markets: an ANN approach". The Journal of Risk Finance, Vol. 8 No. 5, pp. 465-480

Hassan, M. and Bashir, A. (2003), "Determinants of Islamic banking profitability". Paper presented at the ERP 10th Annual Conference in Morroco.

Haron, S. (2004), "Determinants of Islamic Bank Profitability", Global Journal of Finance and Economics. USA, vol 1, No 1.

Handzic, M.T, Rawibawa F. and Yeo J. (2003). "How Neural Networks Can Help Loan Officers to Make Better Informed Application Decisions", Informing Science Insite

How, J. C., Melina, A. K. and Verhoeven, P. (2005), "Islamic financing and bank risks: the case of Malaysia", Thunderbird International Business Review, 47(1), pp.75-94.

Islamic Financial Services Board (IFSB), (2014), Islamic Financial Services Industry Stability Report (Kuala Lumpur). 
Kamijo, K. and T. Tanigawa, (1990), "Stock Price Pattern Recognition: A Recurrent Neural Network Approach", Proceedings of IEEE International Conference on Neural Networks, IEEE Press, Alamitos, CA, Vol. 1, pp. 215-221.

Koster, A., N. Sondak and W. Bourbia, (1990), “A Business Application of Artificial Neural Network System”, The Journal of Computer Information Systems, Vol. XI, pp. 3-10

Kryzanwski, L., M. Galler and D. Wright, (1993), “Using Artificial Neural Networks to Pick Stock", Financial Analysis Journal, Vol. 12, No. 1, pp. 21-27.

Malhorta R. And Malhorta D.K., (2003), Evaluating Consumer Loans Using Neural Networks, Elsevier Science Ltd.

Mitchell D. and Pavur R., (2002), "Using Modular Neural Networks for Business Decisions”, Management Decision, Vol. 40 Issue 1 pp. 58 - 63

Molyneux, P. and Thornton, J. (1992), "Determinants of European bank profitability: a note", Journal of Banking and Finance, vol.16, pp.1173-1178.

Nienhaus, V. (1983), "Profitability of Islamic PLS Banks Competing with Interest BanksProblems and Prospects", Journal of Research in Islamic Economics, vol. 1 (1), pp. 37-47.

Odom, M. and Sharda, R. (1990), “A neural network model for bankruptcy prediction". Proceedings of the IEEE International Conference on Neural Networks 2, 163-168.

Ravi, V., Kurniawan, H., Thai, P.N.K. and Kumar, P. R. (2008), "Soft computing system for bank performance prediction. Applied Soft Computing”, Volume 8, Issue 1, January 2008, Pages 305-315

Rosly, SA and Abu Bakar MA (2003), "Performance of Islamic and mainstream banks in Malaysia”. International Journal of Social Economics, 30(12), pp.1249-1265.

Samad, A., and Hassan, M. K. (2000), "The performance of Malaysian Islamic Bank During 1984 1997: An Explanatory Study". Thoughts on Economics, 10(1\&2), 7-26.

Sanusi, N. and Mohammed, N. (2005), "Profitability of an Islamic Bank: Panel Evidence from Malaysia", in Sanusi, N. Harun, M and Samsudin, S.(Ed.), Reading in Islamic Economics and Finance, Penerbit Universiti Utara Malaysia, Kedah, pp: 97-116.

Sapuan, N.M. and Roly, M.R. (2015), "Bank Profitability and Bank-Specific Variables in Malaysia: A Panel Cointegration and Error Correction Model". Journal of Islamic Finance and Business Research, Vol. 3. No. 1. March 2015 Issue, pp: $50-61$

Surkan, A. and J. Singleton, (1990), "Neural Networks for Bond Rating Improved by Multiple Hidden Layers", Proceedings of IEEE International Conference on Neural Networks, IEEE Press, Alamitos, CA, Vol. 2, pp. 157-162. 
Tam, K.Y. and Kiang, M.Y. (1992), "Managerial applications of neural networks: the case of bank failure predictions", Management Science, Vol. 38, pp. 926-47.

Tsukuda, J. and S. Baba, (1994), "Predicting Japanese Corporate Bankruptcy In Term of Financial Data Using Neural Network", Selected papers from the 16th Annual Conference on Computers and Industrial Engineering, Elsevier Science Ltd., Vol. 27, Nos 1-4, pp. 445-448.

Turen, S (1995), "Performance and risk analysis of the Islamic Banks: The Case of Bahrain Islamic Bank". Journal of Islamic Economics, vol. 7, pp.3 -13.

White, H., (1988), "Economic Prediction Using Neural Networks: The Case of IBM Daily Stock Returns", Proceedings of IEEE International Conference on Neural Networks, IEEE Press, San Diego, CA, pp. 451-459.

Yoon, Y. and G. Swales, (1990), "Predicting Stock Price Performance", Proceedings of the $24^{\text {th }}$ Hawaii International Conference on System Sciences, IEEE Press, Alamitos, CA, Vol. 4, pp. 156-162 